\title{
Um olhar panorâmico para o capitalismo de contradições na obra Dezessete contradições e o fim do capitalismo, de David Harvey
}

\author{
Review of the book Dezessete contradições e o fim do capitalismo
}

\author{
Bruno Leonardo S. Barcella ${ }^{A}$ \\ ${ }^{a}$ Doutorando do Programa de Pós-Graduação em Geografia da Unesp de Presidente Prudente. \\ E-mail: blbarcella@gmail.com
}

HARVEY, D. Dezessete contradições e o fim do capitalismo. São Paulo: Boitempo, 2016.

Dezessete contradições e o fim do capitalismo foi escrito pelo renomado geógrafo britânico David Harvey, atualmente professor de pós-graduação da Universidade de Nova York (NYU). Foi publicado originalmente em 2014 pela editora Oxford University Press e foi traduzido para a língua portuguesa em 2016, por Rogério Bettoni, em edição publicada pela editora Boitempo.

Harvey examina o que ele denomina de contradições internas do processo de reprodução do capital. Segundo o autor, essas contradições internas dão coerência ao modo de produção capitalista. Ao mesmo tempo, porém, são responsáveis pelo "pontapé" inicial não somente da crise econômica mais recente, observada em escala internacional, mas das crises econômicas cíclicas que ocorrem em diferentes pontos do mundo.

O autor constrói uma análise sistêmica. Constata que, mesmo sendo possível observar que algumas formas de manifestações das contradições do capital são evidentes desde a época em que Marx escreveu, principalmente, O Capital e Grundrisse, elas projetam e conformam até hoje a materialidade da vida sob a "égide do capital".

O livro tem três partes, além do prólogo, da introdução e da conclusão, e cada uma destas procura construir argumentos que comprovem a existência de 17 contradições. Mais do que isto, o autor busca explicá-las de forma a mostrar suas conexões com o surgimento das crises. $\mathrm{O}$ autor entende as crises fundamentais para o rearranjo das contradições do atual sistema de acumulação pautado pelo crescente domínio das lógicas financeiras.

Na primeira parte, intitulada "As contradições fundamentais", o autor aborda as sete primeiras contradições, entendidas como fundamentais para o funcionamento do processo de reprodução do capital. Sem elas, o sistema de acumulação, cujos princípios são observáveis "em qualquer época ou lugar", não pode se reproduzir. O autor dá os seguintes nomes a essas contradições: 1. "valor de uso e valor de troca"; 2. "o valor social do trabalho"; 3. "propriedade privada e Estado capitalista"; 4. "apropriação privada e riqueza comum"; 5. "capital e trabalho"; 6. "capital como processo ou como coisa?"; 7. "a unidade contraditória entre produção e a realização".

A segunda parte do livro, "As contradições mutáveis", aborda outras sete contradições envolvendo a dinâmica do capital na evolução histórica e geográfica. De acordo com o autor, elas, por sua vez, correspondem às que não são estáveis ou permanentes, mudando sempre de lugar. São contradições relativas a outras condicionantes. São elas: 1. "tecnologia, trabalho e descartabilidade humana"; 2. "divisões do trabalho"; 3. "monopólio e competição: centralização e descentralização"; 4. "desenvolvimento geográficos desiguais e produção do espaço"; 5. "disparidades de renda e riqueza"; 6. "reprodução social"; 7. "liberdade e dominação".

Nesta segunda parte, a exposição dos argumentos do autor ganha complexidade, à medida em que passa a debater as contradições consideradas mutáveis. Ele abre as contradições do capital para a interação com as do capitalismo e avalia as suas formas no tempo e no espaço. Com essa opção de construção analítica, o autor transborda os debates comuns de análises generalizantes e homogeneizantes.

Com recursos típicos de análises geográficas, nesta segunda parte o autor considera o papel crucial e central das articulações de escalas que envolvem o processo de reprodução do capital. Dá justo destaque ao desenvolvimento 
desigual das regiões. Aborda como o Estado acaba por legitimar e apoiar a acumulação por espoliação em diferentes realidades de acordo com cada condicionante.

A terceira e última parte, intitulada "As contradições perigosas", trata de apenas três contradições. Essas contradições perigosas, por vezes, são fatais. $\mathrm{O}$ autor ressalta que tais contradições estão dentro das contradições que Marx apontava como possivelmente fatais para a reprodução do capital. Podem levar a um colapso do sistema, conduzindo à sua superação. "É famoso que Marx tenha dito que o capital acabaria em colapso sob o peso de suas próprias contradições internas" (p. 220).

Dentro dessa perspectiva, Harvey constrói a terceira e última parte do livro, com destaque para essas três contradições: 1. "crescimento exponencial perigoso"; 2. "a relação do capital com a natureza"; 3. "a revolta da natureza humana: alienação universal".

Harvey aborda essas "contradições perigosas" como extremamente danosas e perversas, pois elas podem provocar uma degradação progressiva da terra e um empobrecimento em massa, aumentando radicalmente a desigualdade social e a desumanização de grande parte da humanidade.

Ao final do livro, o autor busca apresentar uma síntese ousada, com todas as ressalvas e problematização que a questão merece, ao propor 17 "ideias para a prática política". Essa exposição é um manifesto "revolucionário", contendo direcionamentos e orientações para desafiar e superar o regime capitalista. Da mesma forma que apresenta as 17 contradições do funcionamento de reprodução do capital, Harvey propõe "contrapartidas". Por conta dessa ousadia, o próprio autor considerou este "livro o mais perigoso" que já escreveu.

Cabe destacar que Harvey afirma trabalhar com as contradições do capital, e não com as do sistema de produção capitalista. Tal ideia deriva da busca e objetivo de se propor a entender como o motor econômico do capitalismo funciona e porque, quase sempre, o sistema de acumulação capitalista chega em um ponto de inflexão que beira um colapso fatal. Tal ponto de inflexão resulta da conjugação destas diferentes contradições que fazem parte do funcionamento interno do processo de acumulação. Desde o início do livro, o autor ressalta que tais "crises são essenciais para a reprodução do capitalismo" (p. 9).

Uma ideia importante de Harvey e que parece central em sua argumentação é que as contradições apresentadas e discutidas são extremamente relevantes para estudos em diversas áreas do saber. Ele articula muito bem as sinergias dessas contradições com o movimento de acumulação do capital que, na perspectiva adotada, acaba por moldar as estruturas vigentes. Esse exercício de compreensão de como o capital se move de forma contraditória permite que se utilize esse conhecimento para examinar materialidades concretas, tendo em vista que são elementos estruturais presentes na própria dinâmica do capital.

Por fim, Harvey apresenta uma conclusão que não é nova em sua obra: ele constata que as crises são essenciais e fazem parte da constituição e da reprodução do capital. É nas crises que o capital é confrontado e reformulado e gera como resultado novas formas e estruturas. As crises são produtos também das contradições internas do capital. Uma delas é a contradição existente entre Estado e propriedade privada, trabalhada no livro como uma contradição fundamental.

\section{REFERÊNCIA}

HARVEY, D. Dezessete contradições e o fim do capitalismo. São Paulo: Boitempo, 2016. 